\title{
Interferon- $\alpha-\mathrm{A}(\mathrm{IFN}-\alpha-\mathrm{A})$ Diversity in Domestic Yak (Bos grunniens) of Pakistan

\author{
M. Ellahi Babar, T. Hussain, A. Ali, A. Aftab, M. Sohail, M. Ali, Q.-ul-Ain, \\ A. Wajid, F. M. M. T. Marikar* and M. M. Musthafa
}

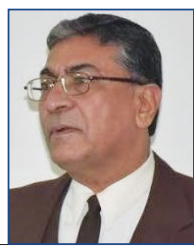

\section{Abstract}

Among the various species of livestock, the domestic yak (Bos grunniens) belongs to the class Bovidae and is specially adapted for survival at high altitudes under extreme climatic conditions. Yak is a very useful species due to the multiple products it provides, such as meat, hide, milk and other dairy products. Like other livestock species, domestic yak is also in danger of infection by microbial infections. However, multiple immunity genes encode special protein products to fight infection. One of these immunity genes is interferon- $\alpha$-A (IFN- $\alpha-A)$, which encodes proteins that belongs to cytokines and fights viral infections. The current study analysed the genetic variation and phylogenetic analysis of the IFN- $\alpha$-A gene in domestic yak, with comparisons to other mammalian species to investigate immune diversity level, with the aim of designing molecular selection strategies for better disease resistant animals.

Key words: domestic; interferon; cytokine; infection; immunity; polymorphism

\section{Introduction}

Domestic yak (Bos grunniens) is a giant cattle species specially adapted to survive under the immensely unfavourable conditions of the Himalayas and Tibetan Plateau (Wiener et al., 2003), at elevations of 4,000 to 6,100 meters (Buzzard and Berger, 2016). The fatty subcutaneous fat layer and long, outer fur help them to survive and resist cold and harsh climatic conditions. Domestic yaks are gregarious, moving in groups of several hundred individuals, though smaller groups of 10-20 individuals are also observed. Mostly feed on grasses, forbs

\footnotetext{
Masroor ELLAHI BABAR, The University of Agriculture, Dera Ismail Khan, Khyber Pakhtunkhwa, Pakistan; Tanveer HUSSAIN, Department of Molecular Biology, Virtual University of Pakistan, Lahore, Pakistan; Akhtar ALI, Anam AFTAB, Qurat-ul-AIN, Abdul WAJID, Department of Biotechnology, Virtual University, Lahore, Pakistan; Mudassir SOHAIL, Department of Livestock and Dairy Development, Gilgit Baltistan, Pakistan; Mastan ALI, Livestock \& Dairy Development Board, Gilgit Baltistan, Pakistan; Faiz Mohideen Mohamed Thassim MARIKAR*, (Corresponding author, e-mail: faiz@kdu.ac.lk), General Sir John Kotelawala Defence University, Kandawala Estate, Ratmalana, Sri Lanka Faculty of Health Sciences, The Open University of Sri Lanka, Nawala, Sri Lanka, Muneeb Mohamed MUSTHAFA, Department of Biosystems Technology, Faculty of Technology, South Eastern University of Sri Lanka, University Park, Oluvil, \#32360, Sri Lanka
} 
and sedges (Buzzard and Berger, 2016). The substantial production of meat and milk with a rich protein and fat content in comparison to other cattle make them highly significant for humans (Li et al., 2011). Many dairy products are obtained from yak milk, including curds, cheese, butter, ghee, etc. (Olsen et al., 1990; Han Jianlin et al., 2000; Wiener et al., 2003; Leslie et al., 2009). The skin, bones and even the dung are valuable and used for various purposes (Olsen, 1990; Wiener et al., 2003; Leslie et al., 2009). Domestic yaks are highly importance in fulfilling the increasing demand for food as the increasing population demands.

The domestic yak genome comprises genes responsible for vast body build, high milk production, thick coat, heat shock proteins, etc. Additionally, various immunity genes aid the domestic yak in survival, such as defence against multiple types of microbial infections encountered during the animal's lifetime. Among these many genes is IFN- $\alpha-\mathrm{A}$, a type 1 class of interferon along with IFN- $\beta$ and IFN- $\omega$ (Platanias et al., 2005).

Interferon- $\alpha$-A belongs to a large family of cytokines and act as first line of defence against viral infection (Pereiro et al., 2008). As body cells such as macrophages are infected by viruses, IFN- $\alpha-\mathrm{A}$ production is initiated before leaving the infected cells and moving towards uninfected cells to bind with receptors of those cells. Interferon sets off a cascade mechanism, and antiviral, antiproliferative, antiangiogenic, genemodulatory and immune-regulatory responses are initiated to fight viruses trying to infect other cells (Pereiro et al., 2008). IFN- $\alpha$-A also plays a rolein boosting host immunity by upregulating antigen presentation by major histocompatibility complex (MHC) antigens (Mantegazza et al., 2013). The aim of this study was to analyse the genetic variation and phylogenetic analysis of the IFN- $\alpha-\mathrm{A}$ gene in Pakistani domestic yak (Bos grunniens) to understand the level of immune diversity in order to design molecular selection strategies for better disease resistant animals. This study will be very promising and pave the way for future studies on other immunity genes to explore the genetic makeup of other mammalian species.

\section{Material and Methods}

Domestic yak blood 39 samples were collected from the Gilgit Bultistan and Swat regions. Animals with typical yak phenotype features were also selected from several breeding areas, such as wild life parks and zoos.

Aseptic blood samples (3 $\mathrm{mL})$ were collected from the jugular veins of domestic yak and kept in $15 \mathrm{~mL}$ Falcon tubes containing anticoagulant (200 $\mu \mathrm{L})$ with ethylenediaminetetraacetic acid (0.5 M EDTA). Blood samples were placed on ice just after collection and brought to the laboratory. Before DNA extraction, samples were stored at $-20^{\circ} \mathrm{C}$. All selected and sampled domestic yaks were handled with care, fulfilling the pertinent guidelines. Animal ID, sex, breed, location of animal, and age were also recorded.

Genomic DNA extraction from blood samples was performed using the standard protocol, involving the lysis of white blood cells, digestion of protein, and finally precipitation after isolation of DNA and purification. Dissolved DNA samples in TE buffer ( $\mathrm{pH}$ 8.0) were stored at $-20^{\circ} \mathrm{C}$ for use in the future. DNA samples were quantified with the help of agarose gel electrophoresis $(0.8 \%)$; for comparison, a standard DNA/ DNA ladder was used. All samples were brought to the same concentration level of $50 \mathrm{ng} / \mu \mathrm{L}$. Specific primers were designed using Primer 3 software and the Insilico PCR web facility (Rozan and Skaletsky, 2000) for the IFN- $\alpha$-A gene from a previously reported sequence 
available from GenBank, National Centre for Biotechnology Information (NCBI). For the amplification of the IFN- $\alpha$-A gene (401 bp) through a thermocycler (Bio-Rad, USA), genomic DNA, a set of primers, dNTPs, PCR buffer, $\mathrm{MgCl} 2$, nuclease free water and DNA polymerase were used according to the standard protocol. The PCR product was analysed through $1.5 \%$ agarose gel electrophoresis, and the amplified bands were visualized under UV light using a gel documentation system (Bio-Rad). The amplified PCR products were precipitated with $80 \%$ ethanol and dissolved in a final volume of 10-15 $\mu \mathrm{L}$ deionized water. DNA quality was checked on $2 \%$ agarose gel before sequencing using an ABI PRISM 3130 XL genetic analyser (Applied Biosystems, USA).

Different population genetics software packages (Ensemble Variant Effect Predictor (SNP Effect Predictor, Fast SNP, and Predict SNP) were used to check the SNPs, homology and phylogenetic relationship of domestic yak (Bos grunniens) with multiple species.

\section{Results and Discussion}

Domestic yak (Boss grunniens) primarily inhabits mountainous areas and is an ionic symbol of Tibet and high altitude areas, and essential to the agriculture economy of the QinghaiTibet Plateau region due to the provision of meat and other basic necessities for Tibetans living at high altitudes (Qiuet et al., 2012). With a current total population size of 14 million, the domestic yak is one of the most important livestock genetic resources and plays an essential role in the life of pastoralists and agropastoralists in the region. Yaks provide basic resources (such as milk, meat, transportation, dung for fuel, and hides for tents) that are necessary for Tibetans and other nomadic pastoralists in highaltitude environments (Qi et al., 2009).
In this study, the interferon-alpha (IFN- $\alpha-\mathrm{A})$ gene in domestic yak was amplified and sequenced to investigate and identify the genetic variations. Overall, 20 SNPs were detected at different positions of the IFN- $\alpha-\mathrm{A}$ gene, where $50 \%(n=10)$ were CT, $35 \%$ $(n=7)$ were AG, $10 \%(n=2)$ were GC and $5 \%(n=1)$ were AC. Three of $20(15 \%)$ detected SNPs c. 62 C $>$ G/C, c.76 G>C and c.186 $\mathrm{C}>\mathrm{A} / \mathrm{C}$ were transversional substitutions, whereas the remaining 17 (85\%) c.64 T>C, c.69 T>C, c.88 C>T, c.95 $\mathrm{C}>\mathrm{T}$, c.116 C>T, с. $117, \mathrm{~A}>\mathrm{G}$, c. $125 \mathrm{G}>\mathrm{A}$, c.177 T>C, c.190 A>G, c.211 T>C, c.216 $\mathrm{G}>\mathrm{A}$, c.225 G>A, c.291 C>T, c.292 A>G, c.296 T>C, c.297 G>A/G and c.252 T>C were transitional substitutions (Table 1). The ratio of $d S / d N$ substitutions at polymorphic sites was also examined by translating the nucleotide sequence into a protein sequence. The analysis showed that $45 \%$ (9 of 20) mutations were synonymous (dS) causing no change at the amino acid level, whereas $55 \% \quad(n=11)$ were non-synonymous $(\mathrm{dN})$ and caused changes in amino acids at their respective positions. Both synonymous and non-synonymous variations play an important role in the regulation of gene expression and polymorphic nature of these SNPs markers, suggesting that they may be useful for mapping complex traits in bovine species, including resistance to infectious disease (Grosse et al., 1999). Nucleotide and the deduced amino acid sequence of domestic yak IFN- $\alpha$-A were also compared with published IFN- $\alpha-\mathrm{A}$ sequences of other animals. The extent of genetic variation was compared with the nucleotide sequence of other closely related species, showed 20 SNPs with Bos taurus and 5 SNPs with Bos indicus (both cattle species), 15 with Bos mutus (wild yak), 21 with Capra hircus (goat), 29 with Ovis aries (sheep), 21 and 22 with Bison bison and Bubalus bubalis (buffalo). 


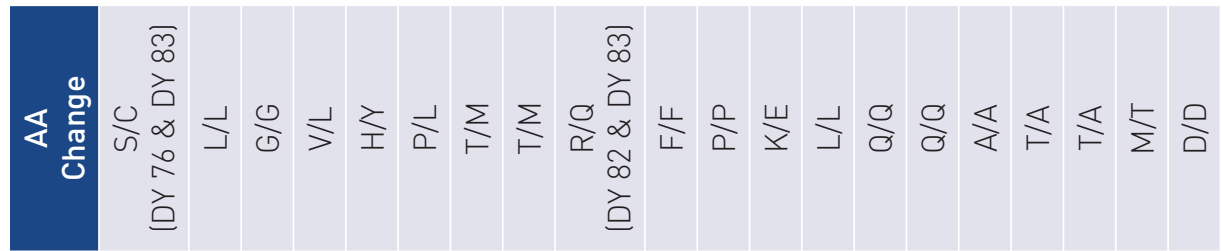

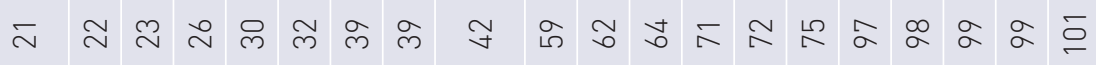

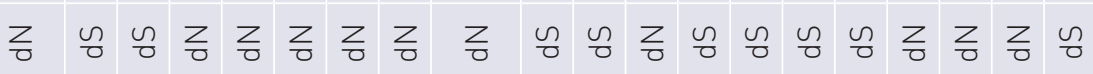

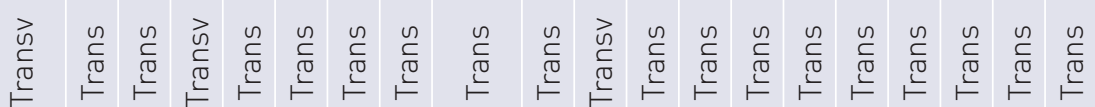

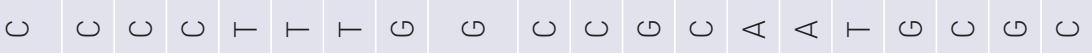

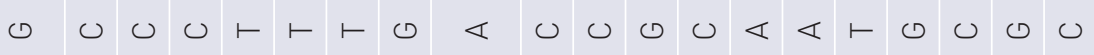


The analysis of translated IFN- $\alpha-\mathrm{A}$ showed the presence of two stretches of conserved amino acids motifs from positions 80-111 and 136-160 that were previously reported in Bos taurus, Bos indicus, Bubalus bubalis, Ovis aries and Capra hircusis, and expected to be significantly associated with the biological activity of the protein. Moreover, the amino sequence showed conserved cysteine residues (Cys24, Cys52, Cys122 and Cys162) that are conserved in most mammalian species and involved in the formation of two di-sulphide bridges necessary for the antiviral activity of interferons (Panday et al., 2015).

Moreover, the homology of domestic yak with other bovine and caprine species was analysed through the BLAST (Basic local alignment Search Tool) program, and showed high similarity with Bos grunniens $(97.59 \%)$ followed by Bos indicus (97.19\%), Bubalus bubalis (97.02\%), Bos taurus (96.84\%), Bison bison (96.84\%), Capra hircus (95.96\%), Ovis aries (95.26\%), Bos mutus (94.21\%), Antilo pecervicapra (94.04\%), Orcinus orca (87.85\%), Odocoileus virginianus (93.51\%), Sus scrofa $(83.22 \%)$ and Homo sapiens (75.85\%) (Table 2). However, IFN- $\alpha$-A gene sequences were highly conserved among different mammalian species. A similar extent of conservation showing a higher degree of homology ( $97 \%$ in nucleotide sequence and $93 \%$ in amino acid sequence) in the gene family of interferon (IFN- $\alpha-\mathrm{A}$ ) consisting of five members in the bovine genome has been reported (Velan et al., 1984).

The phylogenetic analysis of domestic yak of Pakistan was based on the nucleotide sequence of the IFN- $\alpha-\mathrm{A}$ gene and compared with previously published IFN- $\alpha$-A gene sequences of related species retrieved from GenBank. Evolutionary history was inferred using the Neighbour-joining method (Saitou et al., 1987), and evolutionary distances were computed using the Maximum Composite Likelihood method (Tamura et al., 2004). The results showed a high level of IFN- $\alpha$-A gene conservation and resemblance among Bos grunniens, Bos indicus, Bos taurus, Bot mutus, Bubalus

Table 2. Similarity of the domestic yak IFN-a-A gene with other mammalian species (\%)

\begin{tabular}{|l|c|c|c|}
\hline Species & Common Name & $\%$ Identity & Accession Number \\
\hline Bos grunniens & Domestic yak (Chinal & $97.59 \%$ & JN835446.1 \\
\hline Bos indicus & Zebu cattle & $97.19 \%$ & XM_019965693.1 \\
\hline Bubalus bubalis & Water buffalo & $97.02 \%$ & XM_025281446.1 \\
\hline Bos taurus & Cattle & $96.84 \%$ & XM_002689533.5 \\
\hline Bison bison & American buffalo & $96.84 \%$ & XM_010848790.1 \\
\hline Capra hircus & Domestic goat & $95.96 \%$ & XM_018052805.1 \\
\hline Ovis aries & Sheep & $95.26 \%$ & XM_027963937.1 \\
\hline Bos mutus & Wild yak & $94.21 \%$ & XM_005910690.1 \\
\hline Antilo pecervicapra & Blackbuck & $94.04 \%$ & FJ959075.1 \\
\hline Odocoileus virginianus & White-tailed deer & $93.51 \%$ & XM_020904914.1 \\
\hline Orcinus orca & Killer whale & $87.85 \%$ & XM_004275042.2 \\
\hline Sus scrofa & Wild boar & $83.22 \%$ & GQ415062.1 \\
\hline Homo sapiens & Human & $75.85 \%$ & KP719981.1 \\
\hline
\end{tabular}




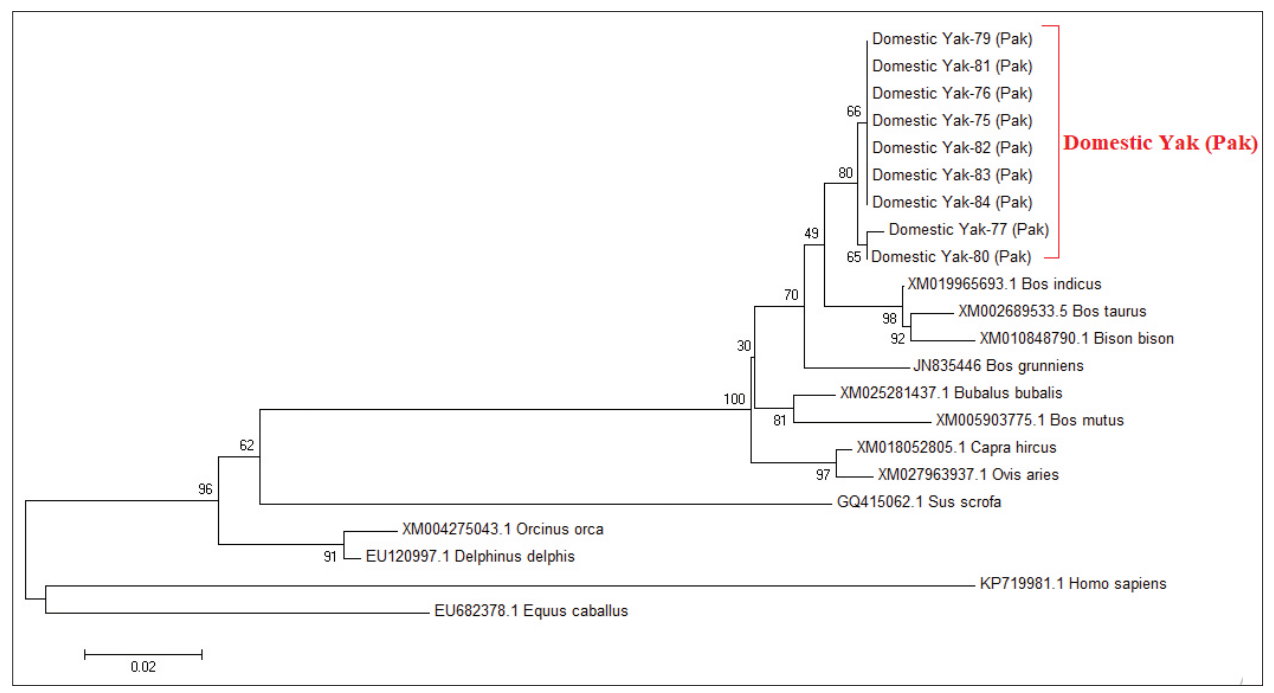

Figure 1. Neighbour-joining phylogenetic tree of Pakistani domestic yak with already reported Bos grunniens, Bos taurus, Bos indicus, Bos mutus, Bison bison, Bubalus bubalis, Ovis aries, Capra hircus, Sus scrofa, Equus caballus, Homo sapiens, Orcinus orca and Delphinus delphis using a bootstrap value of 1000

bubalis and Bison bison, as all these were found in the same clade with the studied domestic yak. Capra hircus and Ovis aries also exhibited high resemblance, whereas high divergence of the IFN- $\alpha$-A gene was shown with common dolphin (Delphinus delphis), killer whale (Orcinus orca), wild boar (Sus scrofa), horse (Equus caballus) and human beings (Homo sapiens) as all these are well distanced from the domestic yak in phylogenetic tree (Figure 1).

Genomic comparisons between closely related species provide insights into the genetic basis of divergence and adaptation in these species. This study is a significant report on the sequence variation in the IFN- $\alpha-\mathrm{A}$ gene of domestic yak in Pakistan, and the polymorphisms detected may assist in the study of associations with disease resistance in animals. However future molecular studies should be conducted to confirm the supposition and to analyse diversities of IFN- $\alpha$-A genes and their antiviral activities among species, breeds and genera to control viral diseases responsible for consistent and serious losses to the livestock industry.

\section{References}

1. BUZZARD, P. and J. BERGER (2016): Bos mutus: The IUCN Red List of Threatened Species.

2. GROSSE, W. M., S. M. KAPPES, W. W. LAEGREID et al. (1999): Single nucleotide polymorphism (SNP) discovery and linkage mapping of bovine cytokine genes. Mamm Genome 10: 1062-1069.

3. HAN JIANLIN, R. C., O. HANOTTE, C. MCVEIGH et al. (2000): Yak production in central Asian highlands. Proceedings of the third international congress on yak held in Lhasa, PR China. International Livestock Research Institute, Nairobi, Kenya

4. LESLIE, D. M. and G. B. SCHALLER (2009): Bos grunniens and Bos mutus (Artiodactyla: Bovidae). Mamm. Species 836, 1-17.

5. LI, H., Y. MA, Q. LI et al. (2011): The Chemical Composition and Nitrogen Distribution of Chinese Yak (Maiwa) Milk. Int. J. Mol. Sci. 12, 4885-4895.

6. MANTEGAZZA, A. R., J. G. MAGALHAES, S. AMIGORENA (2013): et al. Presentation of phagocytosed antigens by MHC class I and II. Traffic 14, 135-152.

7. OLSEN, S. J. (1990): Fossil ancestry of the yak, its cultural significance and domestication in Tibet. Proc. Acad. Nat. Sci. Philadelphia 142, 73-100. 
8. PANDEY, A. K., G. KONDABATTULA, H. J. DECHAMMA et al. (2015): Phylogenetic Analysis of Bovine Interferon $\alpha$. Natl. Acad. Sci. Lett. 38, 75-79.

9. PEREIRO, P., M. M. COSTA, P. DÍAZ-ROSALES et al. (2008): The first characterization of two type I interferons in turbot (Scophthalmus maximus) reveals their differential role, expression pattern and gene induction. Dev. Comp. Immunol. 45, 233244.

10. PLATANIAS, L. (2005): Mechanisms of type I and type II interferon mediated signaling. Nat. Rev. Immunol. 5, 375-386.

11. QI, X. B., H. JIANLIN, G. WANG et al. (2009): Assessment of cattle genetic introgression into domestic yak populations using mitochondrial and microsatellite DNA markers. Anim. Genet. 41, 242-252.

12. QIU, Q, G. ZHANG, T. MA et al. (2012): The yak genome and adaptation to life at high altitude. Nat. Genet. 44, 946-950.
13. ROZAN, S. and J. H. SKALETSKY (2000): Primers on the WWW for general users and for biologist programmers. In: Krawetz S, Misener S, editors. Bioinformatics Methods and Protocols: Methods in Molecular Biology. Totowa, NJ, USA: Humana Press.

14. SAITOU, N. and M. NEI (1987): The neighborjoining method: A new method for reconstructing phylogenetic trees. Mol. Biol. Evol. 4, 406-425.

15. TAMURA, K., M. NEI and S. KUMAR (2004): Prospects for inferring very large phylogenies by using the neighbor-joining method. Proc. Natl. Acad. Sci. 101, 11030-11035.

16. VELAN, B., S. COHEN, H. GROSFELD et al (1984): Bovine Interferon $\alpha$ Genes Structure and Expression. J. Biol. Chem. 260, 549-554.

17. WIENER, G., H. JIANLIN and L. RUIJUN (2003): The Yak. $2^{\text {nd }}$ ed. FAO Regional Office for Asia and the Pacific Food and Agriculture Organization of the United Nations, Bangkok, Thailand. 2003.

\section{Različitost interferona-a-A (IFN-a-A) u jaka (Bos grunniens) iz Pakistana}

Masroor ELLAHI BABAR, The University of Agriculture, Dera Ismail Khan, Khyber Pakhtunkhwa, Pakistan; Tanveer HUSSAIN, Department of Molecular Biology, Virtual University of Pakistan, Lahore, Pakistan; Akhtar ALI, Anam AFTAB, Qurat-ul-AIN, Abdul WAJID, Department of Biotechnology, Virtual University, Lahore, Pakistan; Mudassir SOHAIL, Department of Livestock and Dairy Development, Gilgit Baltistan, Pakistan; Mastan ALI, Faiz Mohideen Mohamed Thassim MARIKAR, Livestock \& Dairy Development Board, Gilgit Baltistan, Pakistan; Muneeb Mohamed MUSTHAFA, General Sir John Kotelawala Defence University, Kandawala Estate, Ratmalana, Sri Lanka

Među različitim vrstama stoke, jedna je vrstaijak (Bos grunniens). Ova životinja pripada obitelji Bovidae. Ova je vrsta prilagođena je preživljavanju na velikim visinama i u ekstremnim klimatskim uvjetima. Jak je vrlo korisna životinja zbog brojnih proizvoda koje od njega dobivamo, poput mesa, kože, mlijeka i mliječnih proizvoda. Kao i druge vrste stoke i jak je u opasnosti od infekcije brojnim mikrobnim infekcijama. Međutim, mnogo je imunogena koji kodiraju posebne proteinske proizvode za borbu protiv infekcija. Jedan od tih imunogena je interferon- $\alpha$-A (IFN- $\alpha$-A) koji kodira proteine koji pripadaju citokinima i bori se protiv virusnih infekcija. Ova studija osmišljena je za analizu genetske varijacije i filogenetsku analizu IFN- $\alpha-A$ gena u jaka (Bos grunniens) te njegovu usporedbu s drugim vrstama sisavaca u svrhu istraživanja razine različitosti imunosti za osmišljenja strategija molekularnog odabira za veću otpornost životinja na bolesti.

Ključne riječi: domaće, interferon, citokin, infekcija, imunost, polimorfizam 